\title{
ARCHAEOMETRICAL STUDIES ON SOME BRONZE BUCKLES WITH PORTABLE (HANDHELD) XRF SPECTROSCOPY
}

\author{
ZOLTÁN MAY*-GERGELY SZENTHE** \\ *Hungarian Academy of Sciences, Research Center for Natural Sciences, \\ Institute of Material and Environmental Chemistry, H-1117 Budapest, Hungary \\ may.zoltan@ttk.mta.hu \\ **Hungarian National Museum, Department of Archaeology, \\ H-1088 Budapest, Hungary, Múzeum krt. 14-16. \\ szenthe.gergely@hnm.hu
}

\begin{abstract}
Portable handheld X-Ray Fluorescence Spectroscopy (pXRF) is very effective and widely used technique for chemical analysis in field of archaeometry. The most advantageous feature of this technique is the possibility of analysing objects, artefacts on the spot without any sample-taking. In this study raw materials of 31 buckles from $7^{\text {th }}$ century AD made of various kinds of bronze and silver alloys were analyzed to check similarities or differences between these objects via chemical analysis. Concentration ratios and distributions of alloying $(\mathrm{Cu}, \mathrm{Sn}, \mathrm{Pb}, \mathrm{Ag})$ and minor elements $(\mathrm{Sb}, \mathrm{Bi}, \mathrm{Zn}, \mathrm{Au})$ in material of bronze artifacts may have useful information suggesting important data about provenance and technology. Our recent study 27 bronze and 4 silver buckles were analyzed by pXRF and the results were used in statistical evaluation in order to get closer to provenance of raw materials and alloying technologies.
\end{abstract}

\section{INTRODUCTION}

The object-type the single specimens of which are analyzed in the recent paper is a simple but characteristic phenomenon of the 'Early' and 'Middle Avar Period' of the $6^{\text {th }}$ and $7^{\text {th }}$ century. Although the most contemporary buckles and belt fittings in the Carpathian Basin belong to or are derived from a Byzantine, or more generally, European Mediterranean material culture, the buckle type of flat, shield-shaped mount is most probable of EasternEuropean origin.

Technological data expand the results of the morphological analysis. There are but just a few and old measurements for alloy compositions, which are mostly not comparable with the more recent analyses, and which base mainly on younger material (en masse cast artifacts /belt fittings/ of the Late Avar Period, $8^{\text {th }}$ century). ${ }^{1}$ In lack of comparative material the recent project raises more questions than it answers.

Only an extensive program of material composition analyses can bring answers for the questions, whether there are any differences between the material composition of Byzantine cast objects and the object-types of the northern peripheries; and if so, whether there is a cultural or economical significance of the differences; or whether there are chronological changes in the alloy compositions. ${ }^{2}$ As most crucial from the point of view of a technological historical perspective, we can put the question whether tendencies indicating the planned, systematical exploitation and traffic of certain resources will be reconstructable in the future. 


\section{MATERIAL AND METHODS}

The sampling referred to the geographical and chronological groups of the objects revealed by the archaeological evaluation. ${ }^{3}$ The selection is representative for the earlier group of objects (characteristic mainly for Transdanubia) and for the younger group as well (with an accent of the regional distribution East of the Danube, and mostly in well-furnished weapon graves).

This group of buckles was chemically analyzed by X-ray fluorescence method for obtain detailed information about raw material of these specimens. The group consists of 27 bronze (several type) and 4 silver buckles which were produced and used in the $7^{\text {th }}$ century AD and were found (excavated) from several area in Hungary. The portable XRF analyzer used for this study was a Thermo Scientific Niton Xl3t 900 GOLDD+ (Geometrically Optimized Large Area Drift Detector) with $50 \mathrm{kV}$ X-ray tube with silver target (Ag anode). This apparatus has some company-preset calibrations for given matrices and in our case "General Metals" and "Precious Metals" were used (both were applied for silver objects and first one for all the others). For all analysis two energy filters for irradiation were applied including Main, and High filter. The third one (Light filter) was not used in order to get complete and real composition of the studied alloys eliminating non-relevant elements ( $\mathrm{Si}, \mathrm{Al}, \mathrm{Ti}$ ) coming from surface contaminations (soil or dust layer). Measuring time was $60 \mathrm{sec}$. in all cases using 30-30 sec. for each filter. Measuring spot size (irradiation area on the object surface) was $8 \mathrm{~mm}$ in diameter. Before measuring a little area was cleaned and rasped on the surface of every object to remove corrosion products and contaminations (dust, soil, etc.) to measure real material of the buckles. Following elements can be measured by pXRF: $\mathrm{Sb}, \mathrm{Sn}, \mathrm{Cd}, \mathrm{Pd}, \mathrm{Ag}, \mathrm{Ru}, \mathrm{Mo}, \mathrm{Nb}, \mathrm{Zr}$, $\mathrm{Bi}, \mathrm{Pb}, \mathrm{Se}, \mathrm{Au}, \mathrm{W}, \mathrm{Zn}, \mathrm{Cu}, \mathrm{Ni}, \mathrm{Co}, \mathrm{Fe}, \mathrm{Mn}, \mathrm{Cr}, \mathrm{V}, \mathrm{In}, \mathrm{Rh}, \mathrm{Pt}$, Ir, Ga. Among these we used only relevant elements for evaluation data. Standardless fundamental parameters method with Compton-normalization is used by the XRF apparatus for quantitative analysis and results were also checked by viewing the corresponding spectra with NDT software (Niton Data Transfer, version 8.0.0). Mathematical and statistical data processing was done with Excel and Statistica 12 softwares.

\section{RESULTS AND CONCLUSIONS}

Chemical composition data of 27 bronze and 4 silver buckles obtained by pXRF analysis are in Table 1. As it can be seen in the tree diagram (dendogram) in figure 1 the 4 silver buckles form a very different group from the other buckles made of $\mathrm{Cu}$ alloys. The following examination done in present work basically refers to buckles made of bronze. The number of silver buckles studied here is very low (four objects) so there is no use making statistical calculations with these. The main information is the high level of similarity between the two silver buckles from Ozora with number 275.1871.28 and 275.1871.25a (see Fig. 1). There are two bronze objects which was considered to be the parts of the Kunágota grave find and to form a couple although the affiliation was dubious; now by this analysis this is probably proved.

If cluster analysis is performed on the 27 bronze objects without silver ones we get the tree diagram (dendogram) seeing below (Fig. 2) where four main groups can be distinguished with one outlier with significantly high zinc concentration (6.1937.11 from Kecel). From left to right the first group contains five objects with high concentration of lead and tin simultaneously $(69.1858 .13-2 ; 106.950 .2 ; 48.1924 .9 ; 12.1935 .14 ; 22.1932 .101)$. In the next group including 7 objects there are two couples with very similar chemical composition (104.1909.73 and 69.1858.13-1; 55.28.88 and 106.950.13a) despite of their different occurrences. In this group there is a buckle made of almost pure copper ( $>98 \%$, red copper) which is not to be considered as bronze due to this chemical composition. In the third group there are four buckles with higher antimony concentrations (106.950.10a; 48.1924.26; $69.1 .71 ; 69.1 .170)$. In the fourth group (10 objects) there are also two couples of buckles according to their similar material (93.1900.43 and 69.1.42; 37.1887.17 and 69.1.95) but their origins are different either as in the previous case. Performing cluster analysis on the chemical elements can be also informative (see Fig. 3) where grouping of these constituents may carry useful information about raw materials and ores these objects was made of (provenance

\footnotetext{
${ }^{3}$ See SZENTHE in the recent volume.
} 
Tree Diagram for 31 Cases

Ward's method

Euclidean distances

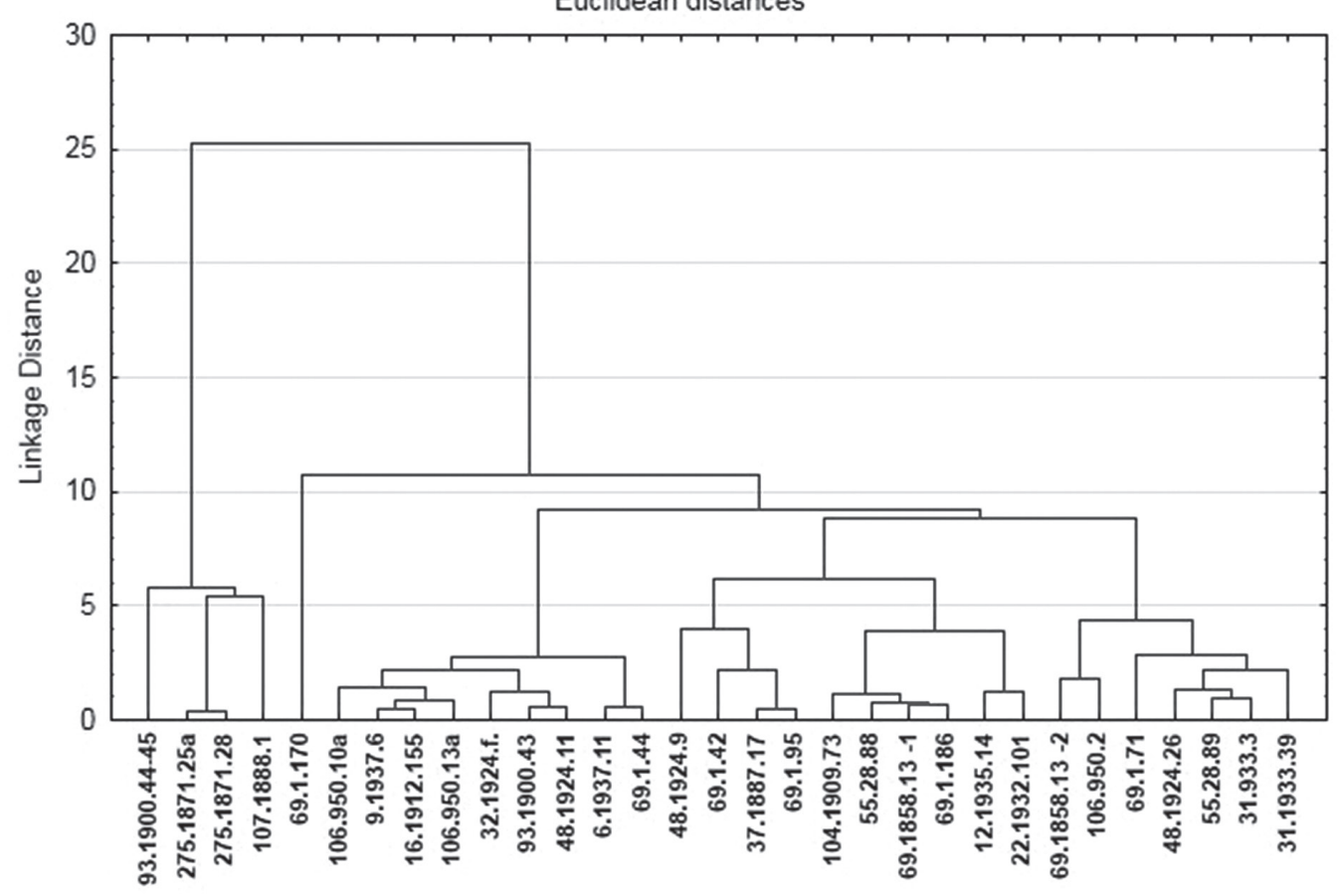

Fig. 1. Result of cluster analysis (dendogram) performed on all the 31 buckles (bronze and silver)

Tree Diagram for 27 Cases

Ward's method

Euclidean distances

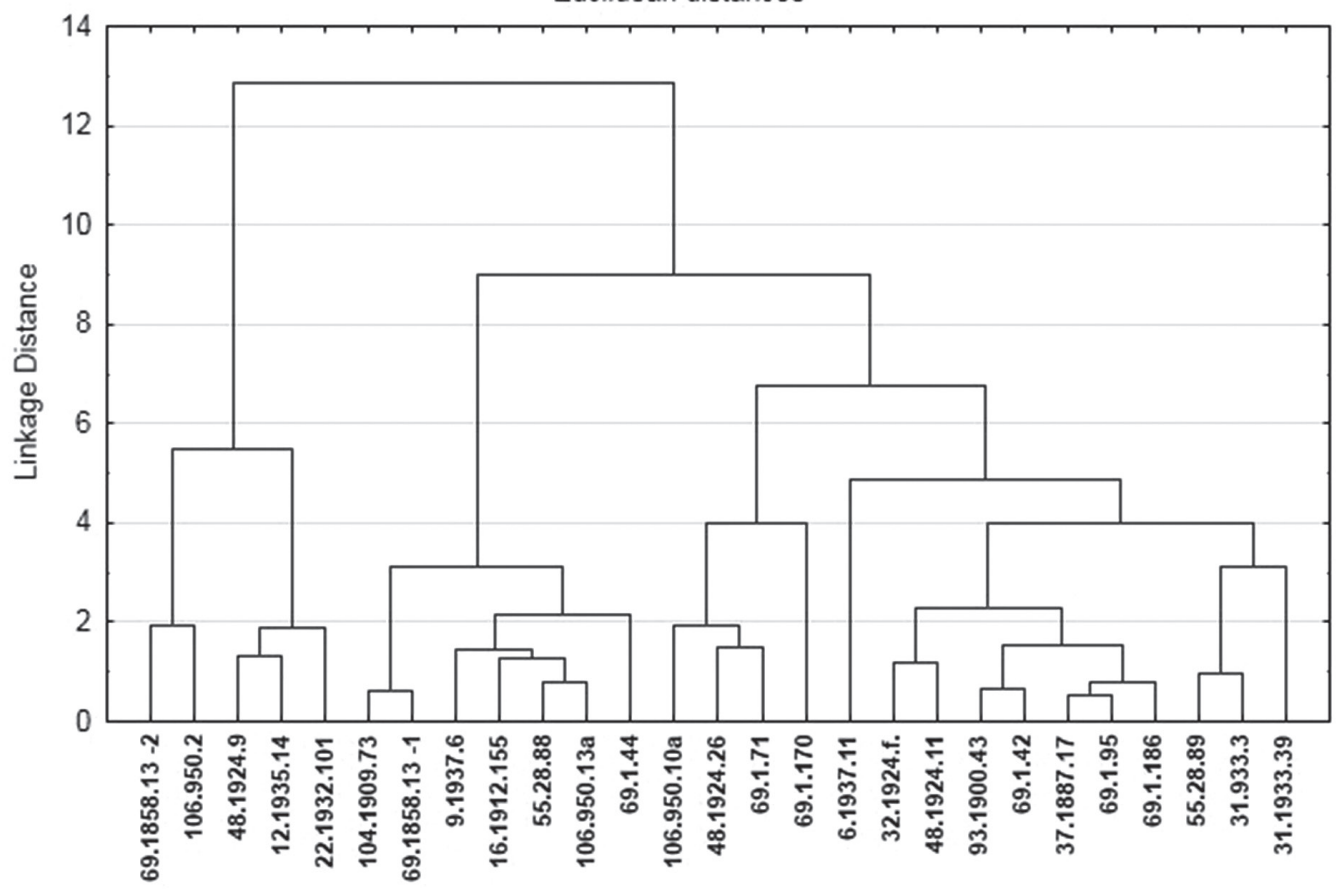

Fig. 2. Result of cluster analysis (dendogram) performed only the 27 bronze buckles (without silver) 


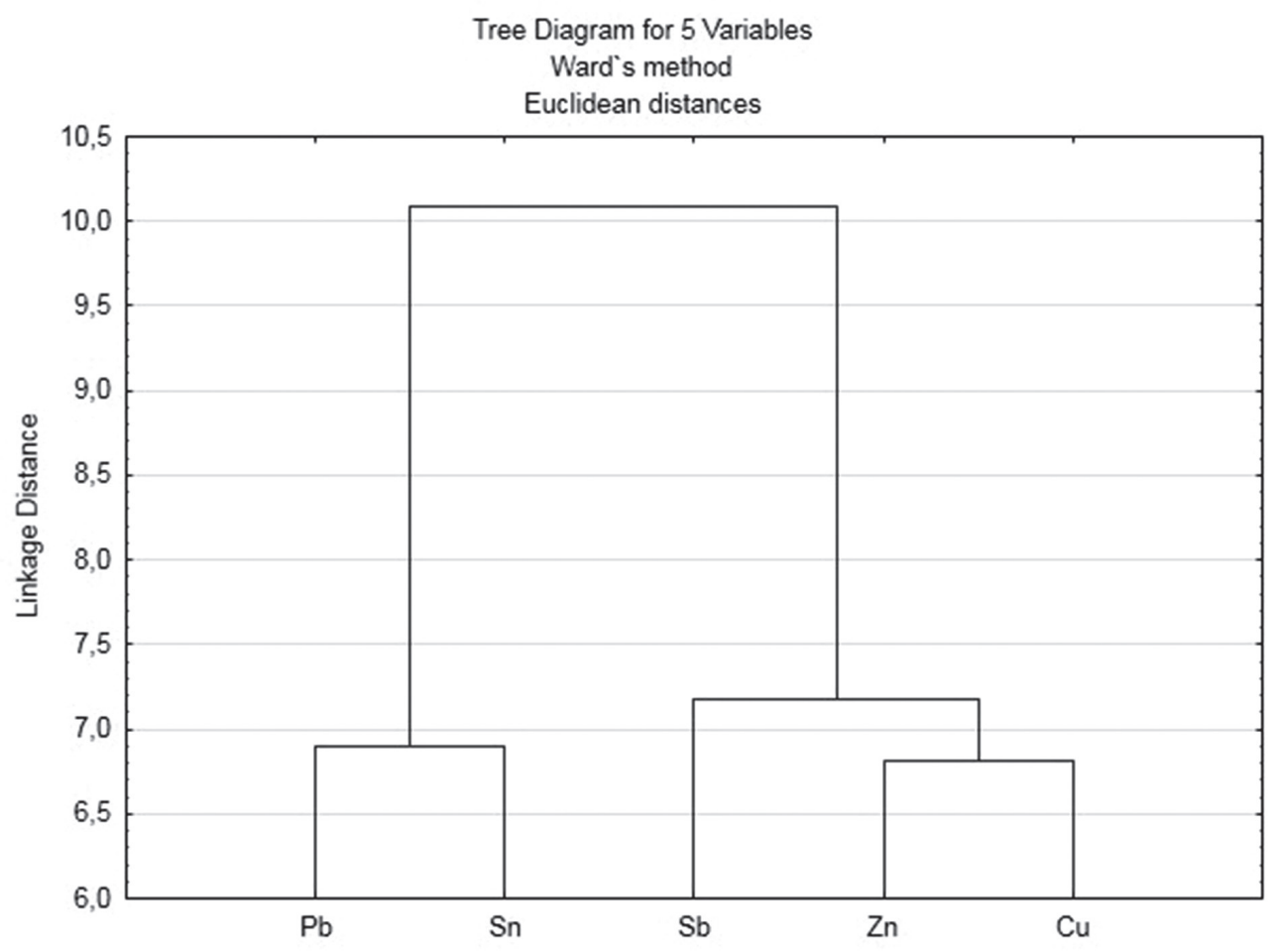

Fig. 3. Result of cluster analysis (dendogram) using the alloying elements

studies). While some buckles with higher concentrations of one or some elements than the others form groups and couples in figures of factor and cluster analysis (Fig. 4a, 4b), the grouping according to their occurrences does not follow these tendencies and does not show these groups (see Fig. 5a, 5b). In principal component analysis (PCA) figures (Fig. 6a, 6b) the chemical elements measured by pXRF can be seen and the directions where a given element or elements dominate which can be compared with factor analysis figures. With this comparison we can clearly see which elements cause separation of the specimens into groups during statistical evaluations. The results in present study show the great heterogeneity of this collection and it is also can be seen that traffic and usage of raw materials and ores was not well organized and well planned. This conclusion is supported by statistical evaluations and figures mentioned above where composition of buckles belonging to given groups varies in wide range. Because of this we will continue this measurement on further objects which will be selected with other historical and archaeological considerations. 


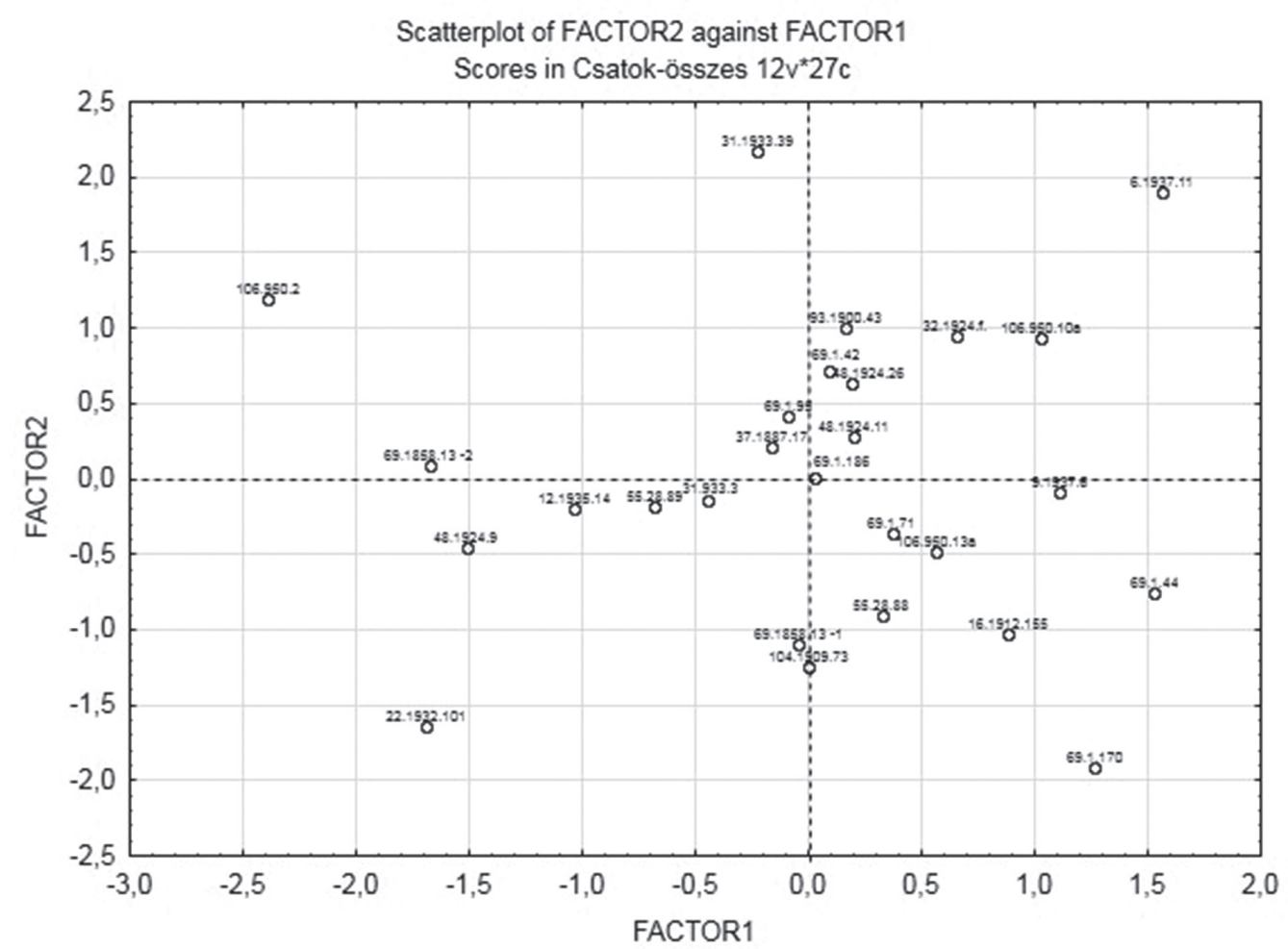

Fig. 4a. Factor analysis performed on the 27 bronze buckles

Scatterplot of FACTOR3 against FACTOR1

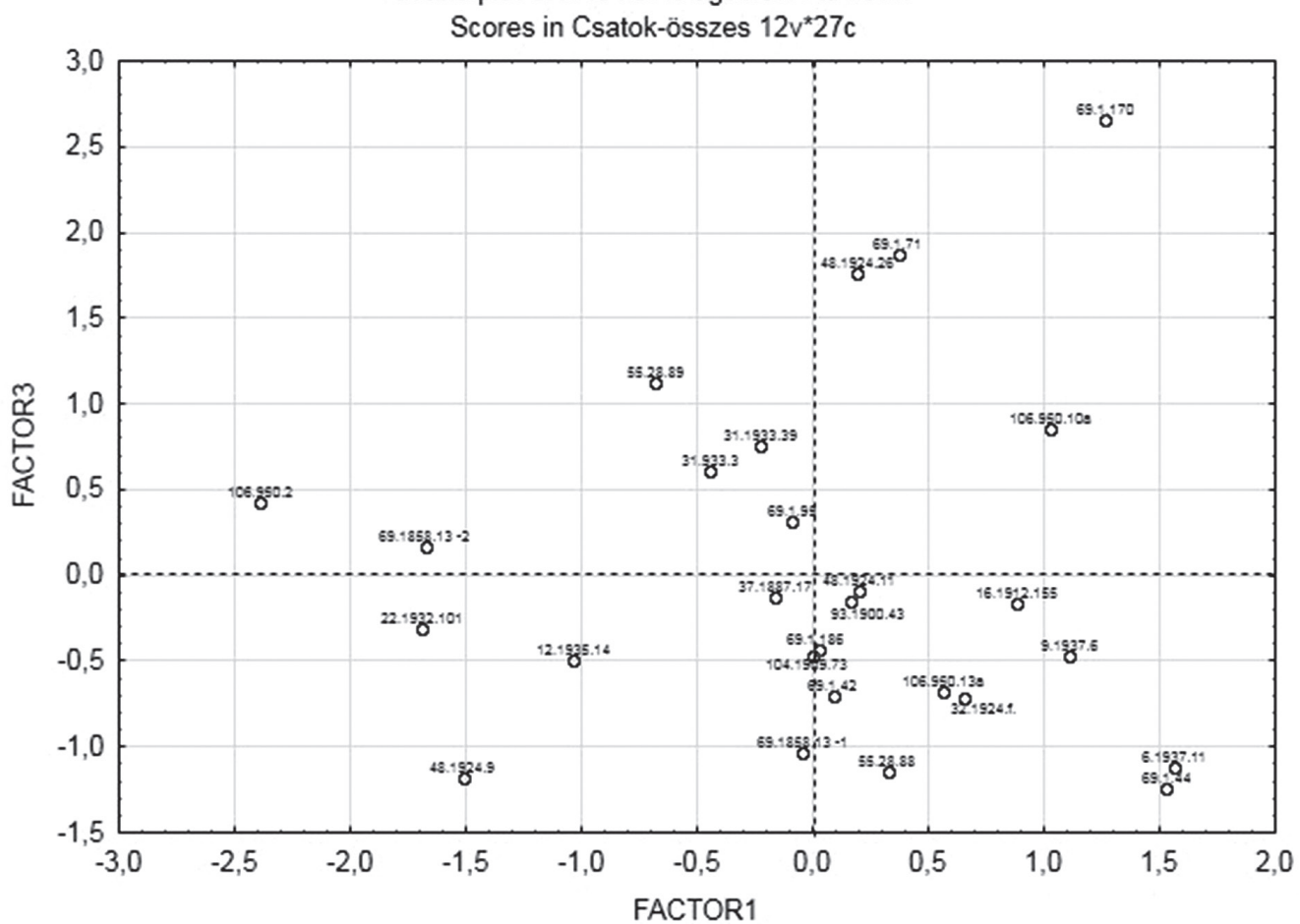

Fig. 4b. Factor analysis performed on the 27 bronze buckles 


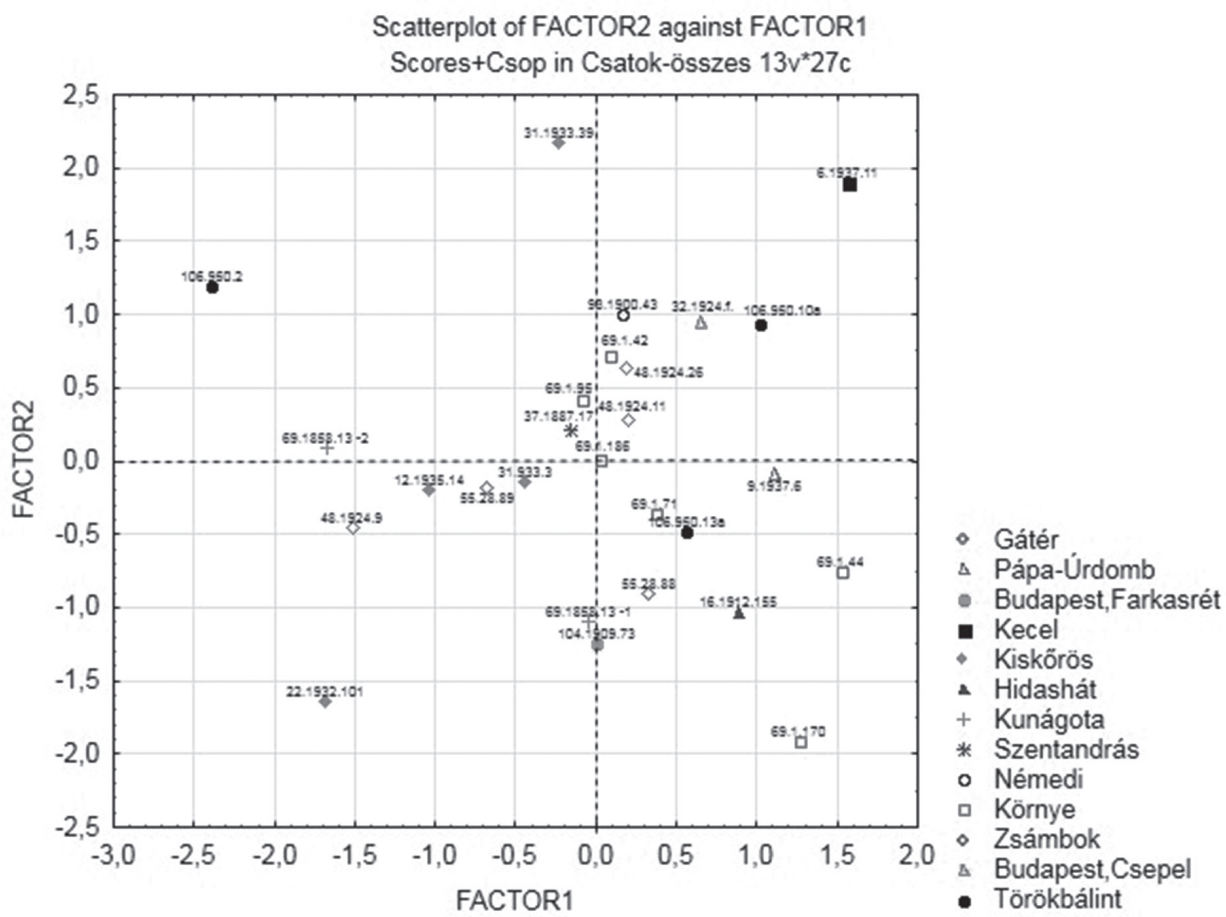

Fig. 5a. Factor analysis performed on the 27 bronze buckles with grouping according their occurrences

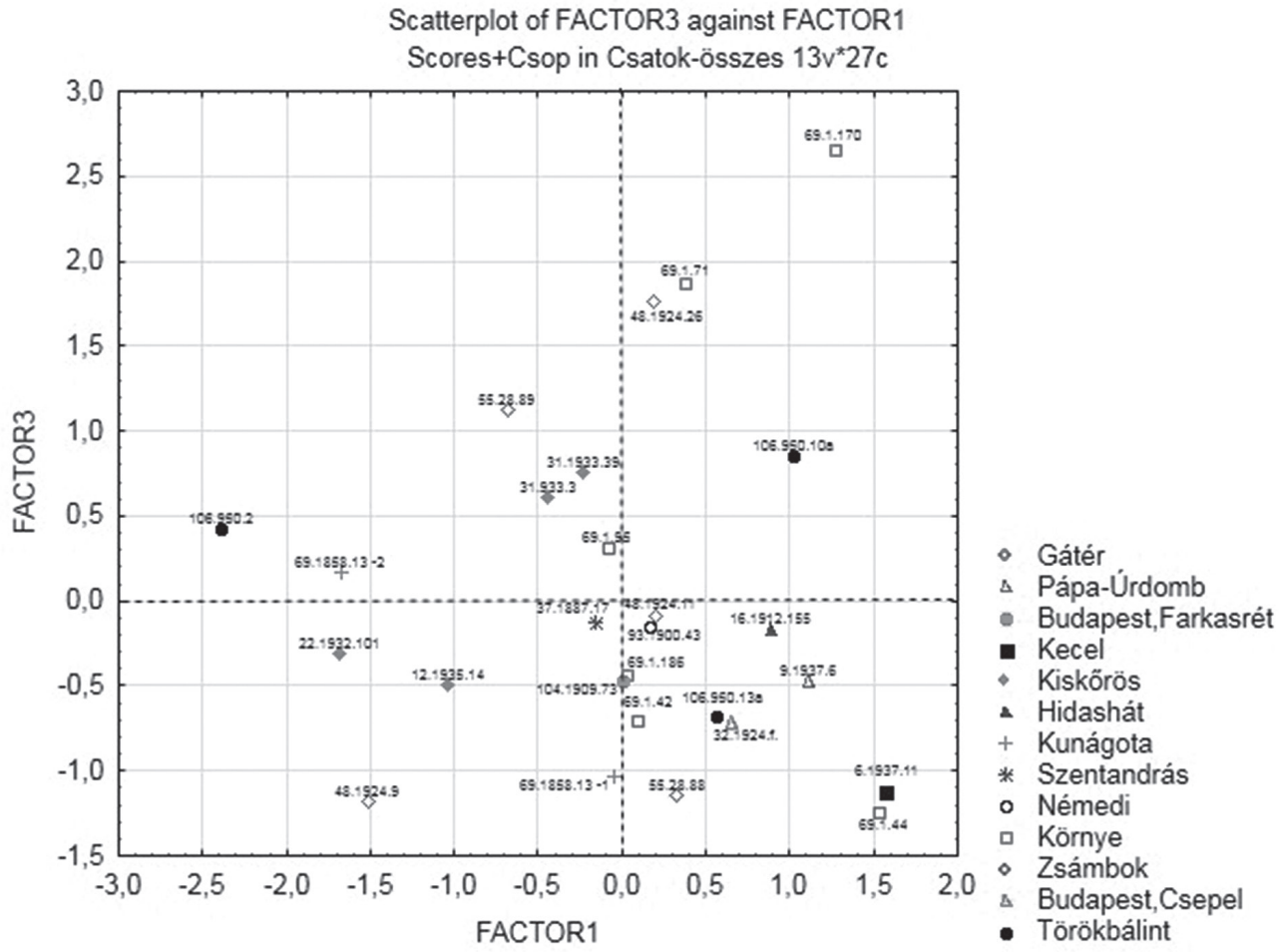

Fig. 5b. Factor analysis performed on the 27 bronze buckles with grouping according their occurences 


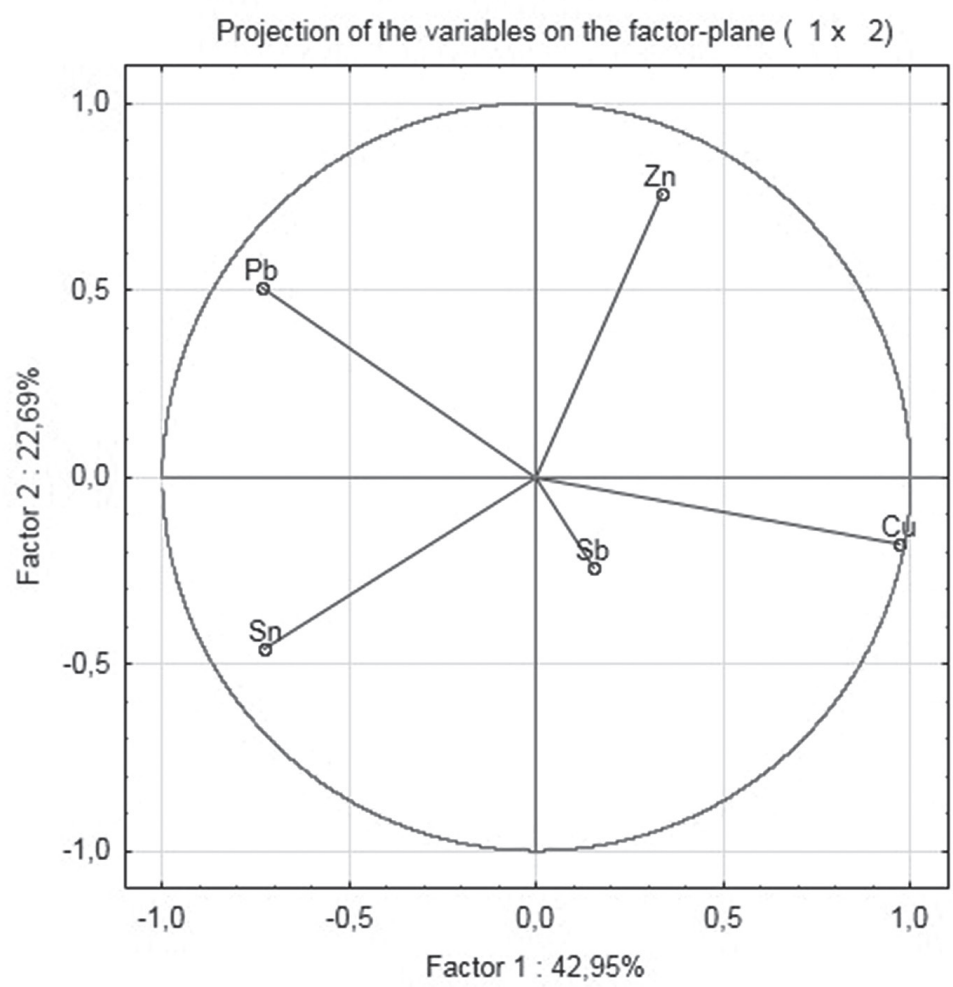

- Active

Fig. 6a. Principal component analyis performed on 27 bronze buckles

Projection of the variables on the factor-plane $\left(\begin{array}{ll}1 \times & 3\end{array}\right)$

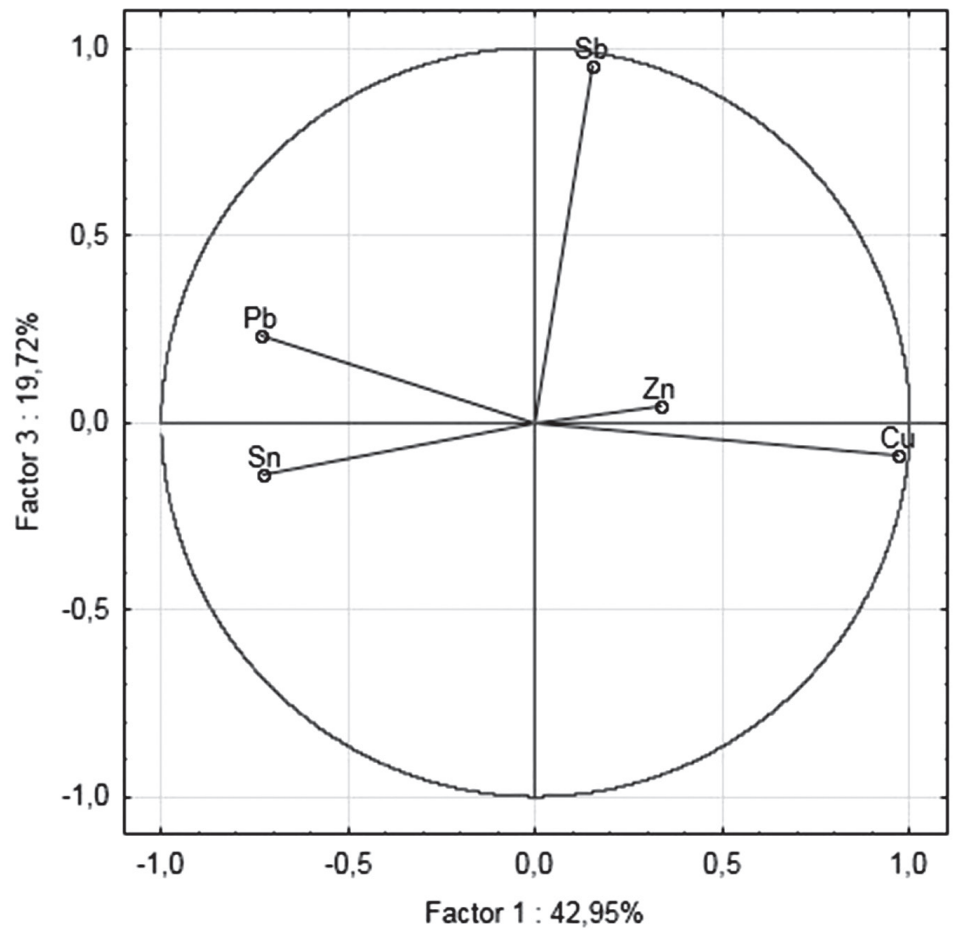

- Active

Fig. 6b. Principal component analyis performed on 27 bronze buckles 
Table 1. Elemental composition of analyzed buckle specimens. Values are in $\% \mathrm{w} / \mathrm{w}$. lod $=$ limit of detection. Lod values in \% w/w: Zn: 0.04; Sb: 0.01; Bi: 0.02; Ag: 0.02; Au: 0.01

\begin{tabular}{|c|c|c|c|c|c|c|c|c|c|}
\hline Cat. Number & Occurance & $\mathbf{C u}$ & Sn & $\mathbf{P b}$ & $\mathbf{Z n}$ & $\mathbf{S b}$ & $\mathbf{B i}$ & Ag & $\mathrm{Au}$ \\
\hline 31.1933 .39 & Kiskőrös & 73.49 & 1.36 & 21.41 & 3.24 & 0.11 & $<\operatorname{lod}$ & $<\operatorname{lod}$ & $<\operatorname{lod}$ \\
\hline 22.1932 .101 & Kiskőrös & 64.79 & 26.61 & 7.70 & 0.16 & 0.11 & $<\operatorname{lod}$ & $<\operatorname{lod}$ & $<\operatorname{lod}$ \\
\hline 31.933 .3 & Kiskőrös & 76.16 & 7.66 & 15.09 & 0.27 & 0.13 & $<\operatorname{lod}$ & $<\operatorname{lod}$ & $<\operatorname{lod}$ \\
\hline 12.1935 .14 & Kiskőrös & 67.93 & 20.88 & 8.06 & 2.32 & 0.09 & $<\operatorname{lod}$ & $<\operatorname{lod}$ & $<\operatorname{lod}$ \\
\hline 69.1 .186 & Környe & 79.11 & 11.25 & 7.00 & 1.94 & 0.09 & $<\operatorname{lod}$ & $<\operatorname{lod}$ & $<\operatorname{lod}$ \\
\hline 69.1 .170 & Környe & 92.24 & 5.99 & 0.71 & $<\operatorname{lod}$ & 0.30 & $<\operatorname{lod}$ & $<\operatorname{lod}$ & $<\operatorname{lod}$ \\
\hline 69.1.95 & Környe & 76.80 & 9.10 & 10.85 & 2.18 & 0.12 & $<\operatorname{lod}$ & $<\operatorname{lod}$ & $<\operatorname{lod}$ \\
\hline 69.1 .71 & Környe & 79.69 & 11.96 & 4.89 & 2.70 & 0.24 & $<\operatorname{lod}$ & $<\operatorname{lod}$ & $<\operatorname{lod}$ \\
\hline 69.1 .42 & Környe & 77.93 & 9.84 & 7.85 & 2.94 & 0.06 & $<\operatorname{lod}$ & $<\operatorname{lod}$ & $<\operatorname{lod}$ \\
\hline 69.1.44 & Környe & 98.03 & 0.61 & 1.04 & 0.04 & 0.05 & $<\operatorname{lod}$ & $<\operatorname{lod}$ & $<\operatorname{lod}$ \\
\hline 48.1924 .9 & Zsámbok & 65.15 & 21.26 & 10.71 & 1.00 & 0.04 & $<\operatorname{lod}$ & $<\operatorname{lod}$ & $<\operatorname{lod}$ \\
\hline 48.1924 .11 & Zsámbok & 81.73 & 5.30 & 11.25 & 1.28 & 0.09 & $<\operatorname{lod}$ & $<\operatorname{lod}$ & $<\operatorname{lod}$ \\
\hline 48.1924 .26 & Zsámbok & 77.81 & 6.32 & 12.38 & 2.70 & 0.21 & $<\operatorname{lod}$ & $<\operatorname{lod}$ & $<\operatorname{lod}$ \\
\hline 106.950 .2 & Törökbálint & 57.02 & 10.36 & 32.01 & 0.12 & 0.08 & $<\operatorname{lod}$ & $<\operatorname{lod}$ & $<\operatorname{lod}$ \\
\hline $106.950 .13 \mathrm{a}$ & Törökbálint & 86.54 & 7.51 & 4.72 & 0.88 & 0.08 & $<\operatorname{lod}$ & $<\operatorname{lod}$ & $<\operatorname{lod}$ \\
\hline $106.950 .10 \mathrm{a}$ & Törökbálint & 85.39 & 3.82 & 6.52 & 3.72 & 0.16 & $<\operatorname{lod}$ & $<\operatorname{lod}$ & $<\operatorname{lod}$ \\
\hline 107.1888 .1 & Ozora & 10.82 & 0.60 & 0.61 & 0.32 & $<\operatorname{lod}$ & 0.10 & 81.92 & 5.51 \\
\hline 275.1871 .28 & Ozora & 12.06 & 0.96 & 3.18 & 0.05 & $<\operatorname{lod}$ & 0.07 & 82.30 & 1.27 \\
\hline $275.1871 .25 \mathrm{a}$ & Ozora & 8.09 & 1.01 & 2.45 & $<\operatorname{lod}$ & $<\operatorname{lod}$ & 0.07 & 87.10 & 1.25 \\
\hline $69.1858 .13-1$ & Kunágota & 81.54 & 13.70 & 3.73 & 0.30 & 0.06 & $<\operatorname{lod}$ & $<\operatorname{lod}$ & $<\operatorname{lod}$ \\
\hline $69.1858 .13-2$ & Kunágota & 64.30 & 14.27 & 20.64 & 0.26 & 0.09 & $<\operatorname{lod}$ & $<\operatorname{lod}$ & $<\operatorname{lod}$ \\
\hline 93.1900 .43 & Némedi & 78.33 & 7.93 & 9.95 & 3.20 & 0.09 & $<\operatorname{lod}$ & $<\operatorname{lod}$ & $<\operatorname{lod}$ \\
\hline $93.1900 .44-45$ & Némedi & 20.65 & 0.56 & 0.50 & 1.75 & $<\operatorname{lod}$ & 0.28 & 74.86 & 1.34 \\
\hline 55.28 .88 & Gátér & 85.74 & 9.14 & 4.45 & $<\operatorname{lod}$ & 0.05 & $<\operatorname{lod}$ & $<\operatorname{lod}$ & $<\operatorname{lod}$ \\
\hline 55.28 .89 & Gátér & 72.54 & 10.95 & 14.87 & 0.82 & 0.17 & $<\operatorname{lod}$ & $<\operatorname{lod}$ & $<\operatorname{lod}$ \\
\hline 104.1909 .73 & Budapest, Farkasrét & 81.45 & 14.23 & 3.30 & 0.39 & 0.10 & $<\operatorname{lod}$ & $<\operatorname{lod}$ & $<\operatorname{lod}$ \\
\hline 32.1924.f. & Budapest, Csepel & 84.91 & 2.54 & 9.57 & 2.35 & 0.05 & $<\operatorname{lod}$ & $<\operatorname{lod}$ & $<\operatorname{lod}$ \\
\hline 16.1912 .155 & Hidashát & 90.60 & 5.52 & 3.31 & 0.06 & 0.11 & $<\operatorname{lod}$ & $<\operatorname{lod}$ & $<\operatorname{lod}$ \\
\hline 37.1887 .17 & Szentandrás & 77.06 & 9.95 & 10.17 & 1.77 & 0.10 & $<\operatorname{lod}$ & $<\operatorname{lod}$ & $<\operatorname{lod}$ \\
\hline 9.1937 .6 & Pápa-Úrdomb & 90.36 & 4.41 & 2.87 & 1.80 & 0.09 & $<\operatorname{lod}$ & $<\operatorname{lod}$ & $<\operatorname{lod}$ \\
\hline 6.1937 .11 & Kecel & 89.74 & 2.30 & 2.22 & 5.40 & 0.04 & $<\operatorname{lod}$ & $<\operatorname{lod}$ & $<\operatorname{lod}$ \\
\hline
\end{tabular}

\section{REFERENCESS}

DAIM 1987

DAIM 2000

KÖLTŐ 1982
= F. DAIM: Das awarische Gräberfeld von Leobersdorf, Niederösterreich. Studien zur Archäologie der Awaren 3. Wien 1987.

= F. DAIM: „Byzantinische” Gürtelgarnituren des 8. Jahrhunderts. In: F. Daim (Hrsg.): Die Awaren am Rand der byzantinischen Welt. Monographien zur Frühgeschichte und Mittelalterarchäologie 7. 2000, 77-204.

= L. KöLTŐ: Avar kori bronztárgyak röntgenemissziós analizise (X-ray emission analysis of bronze objects from the Avar Age). SMK 5/1 (1982) 5-68. 